\title{
Historein
}

Vol 15, No 1 (2015)

Revisiting Democratic Transitions in Times of Crisis

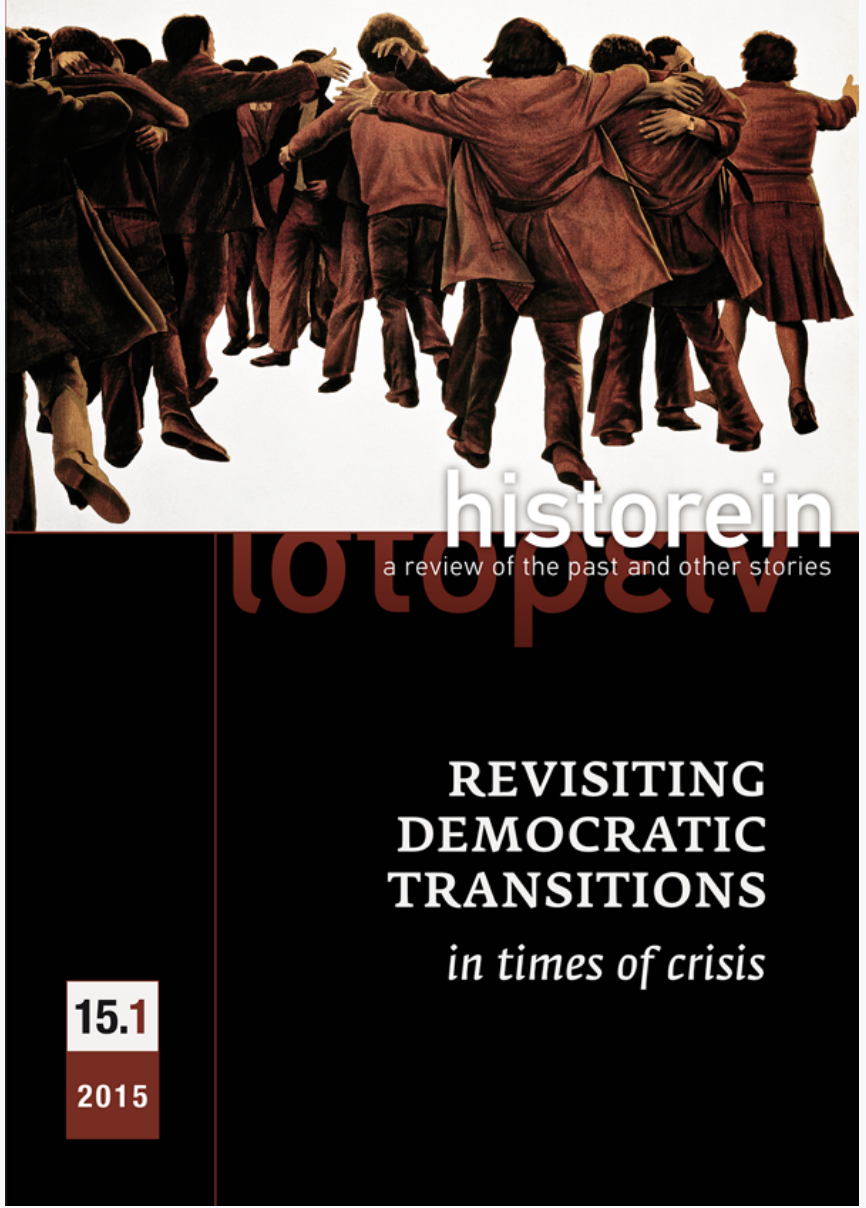

Review of Julia P. Cohen's Becoming Ottomans: Sephardi Jews and Imperial Citizenship in the Modern Era

Darin Stephanov

doi: $10.12681 /$ historein.307

Copyright $\odot$ 2015, Darin Stephanov



This work is licensed under a Creative Commons Attribution-NonCommercialShareAlike 4.0.

To cite this article:

Stephanov, D. (2015). Review of Julia P. Cohen's Becoming Ottomans: Sephardi Jews and Imperial Citizenship in the Modern Era. Historein, 15(1), 157-160. https://doi.org/10.12681/historein.307 
work - and indeed she succeeds in this impeccably and most eloquently - she succumbs to Komnene's historical pretensions, her skilful and persuasive artistry of distortion. On this front, that is, on Anna the historian, Buckley is rather defensive and loses her otherwise self-possessed scholarly insight. Komnene has not "raised a monument to an emperor, a civilisation, an age and to the discipline of history itself" (44) but a distorting mirror whose biased reflection - Alexios and his conservative theocratic autocracy - eased her nostalgia and compensated for the bitter taste of her distressing isolation from the exercise of power. The Alexiad is most definitely a good read in the guise of history, but as with every guise meant to be used as a historical source and not as mere recreational fiction, it demands our constant vigilance and caution.
Julia P. Cohen

\section{Becoming Ottomans: Sephardi Jews and Imperial Citizenship in the Modern Era}

\section{Oxford: Oxford University Press, 2014. xxi + 219 pp.}

\section{Darin N. Stephanov}

Ella and Georg Ehrnrooth Foundation, Helsinki

This book begins and ends by way of references to the contemporary activities of a Turkish organisation headed by Jewish and Muslim entrepreneurs, named the Quincentennial Foundation, in celebration of the passage of five centuries since Sultan Bayezid II welcomed the expelled Sephardi (Ladino-speaking) Jewry of Habsburg Spain into the Ottoman empire in 1492. This choice seems only appropriate given that, in the author's own words, "the aim of the book is to present the story of Jewish allegiance to the Ottoman state not as the history of a sentiment, but rather as the history of a process and a project" (4). She explicitly identifies it as a nineteenth-century phenomenon of internal modernisation in conjunction with wave upon wave of Ottoman reforms effecting fast changing social realities. To this end, the book's main body is divided into four chronological chapters, each of which is centred on one or more significant historical events affecting Ottoman Jewish communities (especially the largest ones, in Salonica, Izmir and Istanbul), beginning with the promulgation of the first Ottoman constitution in 1876 , followed by the 1877-78 Russo-Ottoman war, and ending with Sultan Mehmed V Reshad's 1911 visit to Salonica. The author places special emphasis on the mapping of communal self-perceptions and intracommunal debates on a number of issues surrounding the nature and gamut of acceptable manifestations of 
imperial patriotism, which, as she eloquently puts it, "had to be taught and learned, and, later, maintained and managed" (4).

Chapter one, entitled "Lessons in imperial citizenship", brings into focus various Jewish initiatives ranging from acts of interconfessional philanthropy to outbursts of imperial patriotism, such as volunteering for mixed military units and calls for self-sacrifice in the name of "nation" and "homeland". In addition to citizenship, the author deploys a concept of "civic Ottomanism" as an overarching frame, stressing the self-professed backwardness of the Jewish community vis-à-vis other non-Muslim communities which drove consequent attempts at accelerated cultural integration towards increased domestic visibility and recognition, especially by the state. However, despite the fascinating array of sources Cohen draws on, including tantalising quotes from communal leaders in the capital and the provinces, as well as voices of dissent and even grassroots resistance, there is no sustained discussion of the key concepts of belonging, starting with the actual words used by the interlocutors and proceeding to their shades of potential meaning.

Chapter two is pivoted on two quadricentennials - of the Jews of Spain finding refuge in the Ottoman Empire in 1492, and of Columbus' discovery of America that same year, which inspired the World's Columbian Exposition of 1893. Relating in minute detail the twists and turns in the planning of the former, domestic celebration, the author does an admirable job on many levels. First, she convincingly dispels some myths spawned by previous scholars as to the central origins and timeless nature of a festivity, which in fact began as the idea of a provincial community leader (Aron de Yosef Hazan of Izmir) in 1891. Second, she points to a possible source of his inspiration in the cente- nary celebration of French Jews observed during the same year. Third, she skilfully pieces up the uneven story of the holiday's preparation, marred by many breaks in communication between province and centre, embodied by the chief rabbi. In the process, she demonstrates that rather than a resounding success that cemented the Jewish community's relations with the Ottoman authorities, this celebration narrowly avoided being a communal liability. Fourth, against the background of contemporary Jewish emigration from the Russian empire on a large scale, in the face of pogroms, Cohen insightfully reveals the added dimension of this holiday's invention, from the outset, as a plea to the sultan to accept more Jewish refugees into the Ottoman empire. What is puzzling to this reviewer is that this important geopolitical consideration does not figure in the author's analysis of the eventual, subdued shape the holiday took on. In a related fashion, although Cohen convincingly traces the story of the chief rabbinate's wresting the event away from its passionate local progenitors and their visions of a highly publicised, community-owned, secular ceremony, the sultan is remarkably absent from the scene, while his opinion is conveyed entirely through statements made by the chief rabbi.

As Cohen makes clear, the second quadricentennial was different from the first in almost every respect, save the fact that the company that was granted the Ottoman concession at the World's Columbian Exposition belonged to a Jewish merchant and philanthropist, Elia Souhami. Following the course of the erection of the "Turkish Village", which was supervised by Robert Levy, an engineer and company representative, one cannot fail to notice the integrative, patriotic nature of this all-Ottoman venture. On the one hand, this observation is borne out by the set of Ottoman architectural landmarks which were replicated at the fair. 
These included Yeni Cami (New Mosque) and the famous obelisk at Sultan Ahmet Square, as well as bazaar and street reconstructions of Istanbul's Tuesday Market and Üsküdar neighbourhood, respectively, to name but a few. On the other hand, while very much present in the American public's view, Robert Levy projected a spotless image of a patriotic "Turk" to the utter exclusion of any traits of his Jewishness. Not surprisingly, this section contains the sole direct reference to "beloved homeland" (in Ladino, querida patria) to be found on the pages of the book, in the context of describing the nostalgia stirred up in native Istanbul residents upon encountering the Ottoman exhibits at the fair.

The third chapter delves into another dimension of the highly complex and mercurial project of integrative imperial belonging, namely, the dynamics of intercommunal (that is, interfaith) relations in times of crisis, such as the 1896 anti-Armenian riots in Istanbul or the 1897 Ottoman-Greek war raging not far from Salonica. Drawing on the work of anthropologist James Scott, as she does throughout the book, Cohen adeptly reconstructs both the "public transcripts" and the "hidden transcripts" of various instances, both proven and purported, of Jewish-Armenian and Jewish-Greek interaction on the individual and group levels during these traumatic events. Though she is not always able to explain it, Cohen correctly acknowledges the accelerating trend towards Jewish alignment with the ever stronger Muslim majority in the empire and the consequent shaping of a public discourse she refers to as "Islamic Ottomanism". This chapter's conclusion contains the book's most complete and multilayered definition of the Jewish project under investigation - "patriotism in a particular packaging, wrapped up in middle-class notions of propriety, moderation, and duty as well as modern civil and urban belonging" (100).
The last chapter may well be the book's best. Against the background of the Young Turk Revolution of 1908 and the reinstatement of the 1876 Ottoman constitution with all the ensuing transformations in the domestic political sphere, Cohen composes an engaging narrative of Jewish public life increasingly shaped by intra-communal competition - between Zionists and anti-Zionists, socialist workers and bourgeois liberals, supporters of the new regime and members of the old guard, or on occasion, even between Ashkenazi and Sephardi Jews. The event serving as the stage, both literally and symbolically, for the interplay of most of these rivalries was Sultan Mehmed $\checkmark$ Reshad's visit to Ottoman Macedonia in the summer of 1911. Among the panoply of Jewish celebratory activities welcoming the sultan to the city of Salonica, the pride of place goes to a sequence of triumphal arches raised by social clubs (Club des Intimes and the Nouveau Club), private companies (Allatini), or the Jewish community itself. The most fascinating segments of Cohen's comparative discussion of the respective arches' design, ornamentation and symbolism - which is accompanied by original photographs - interweave disparate recurring motifs of belonging, both complementary and contradictory. Taken together, they reflect the syncretic approach to late imperial attachments where Jewish arches could exhibit objects from the sacred space of the synagogue (such as the silver finials of the law scrolls) without fear of the profanity of the urban public space or be designed in the shape of well-known Muslim (former Christian) sanctuaries from Salonica's cityscape, to give but two examples.

In conclusion, Julia P. Cohen's Becoming Ottomans makes a highly valuable contribution to an accelerating trend in the scholarship on late imperial identities, which undermines the traditionally compartmentalised, insular nature of 
studies of Ottoman religio-linguistic communities. It goes a step further in the direction of weakening the monopoly of now century-old national(ist) historiographies on the narratives of belonging, thereby taking the porosity of intercommunal boundaries back up to historically credible levels. By sifting through a treasure trove of anecdotal evidence in connection to momentous historical events with empire-wide impact, this book invites not only reflection on the Jewish communal trajectory, but even more importantly, to the mind of this reviewer at least, comparative explorations of the experiences and trajectories of other imperial communities, such as Greek- and Bulgarian-Orthodox, Armenian and so on. Therein may lie one of its most lasting legacies in terms of setting a stimulating agenda for future comparative research that will be, more likely than not, along collaborative lines.

\section{Thomas W. Gallant}

The Edinburgh History of the Greeks, 1768 to 1913: The Long Nineteenth Century

\section{Edinburgh: Edinburgh University \\ Press, 2015. viii +372 pp.}

\section{Konstantina Zanou}

Paris Institute of Advanced Studies/

Columbia University

There are four major traps a historian confronts when embarking upon the adventure of devising a new book: first, to write a boring book; second, to write a narrowly framed book which loses sight of the big picture; third, to write a chaotic and labyrinthine book; and fourth, to write a too general, oversimplified and teleological account.

In one masterful movement, Thomas Gallant manages to avoid all of that. His History of the Greeks offers at one and the same time a book that can be taught in class as well as advance the knowledge of experts, be read in the metro as well as discussed at academic conferences, and engage unsuspecting readers as well as surprise specialists. How does he manage to do all of this? To begin with, Gallant seems to enjoy writing. In his book, detailed micro-descriptions and representations of the wider historical context follow one another without the narrative ever losing pace (apart from one moment, as we will see later). Take for instance his chapters on the Greek War of Independence and on the Othonian kingdom: both start from the end and, in the manner of a film that features a story told backwards, they open with a single and powerful retrospective image: the assassination of Kapodistrias and the punishment of the perpetrators, in the first case, and the last sad 